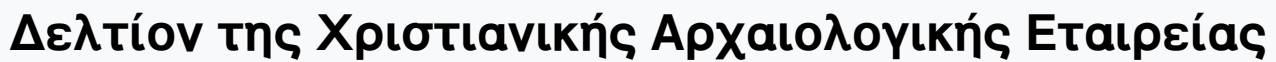

Tó 32 (2011)

$\Delta \varepsilon \lambda$ tíov XAE 32 (2011), Пعрíoঠos $\Delta^{\prime}$

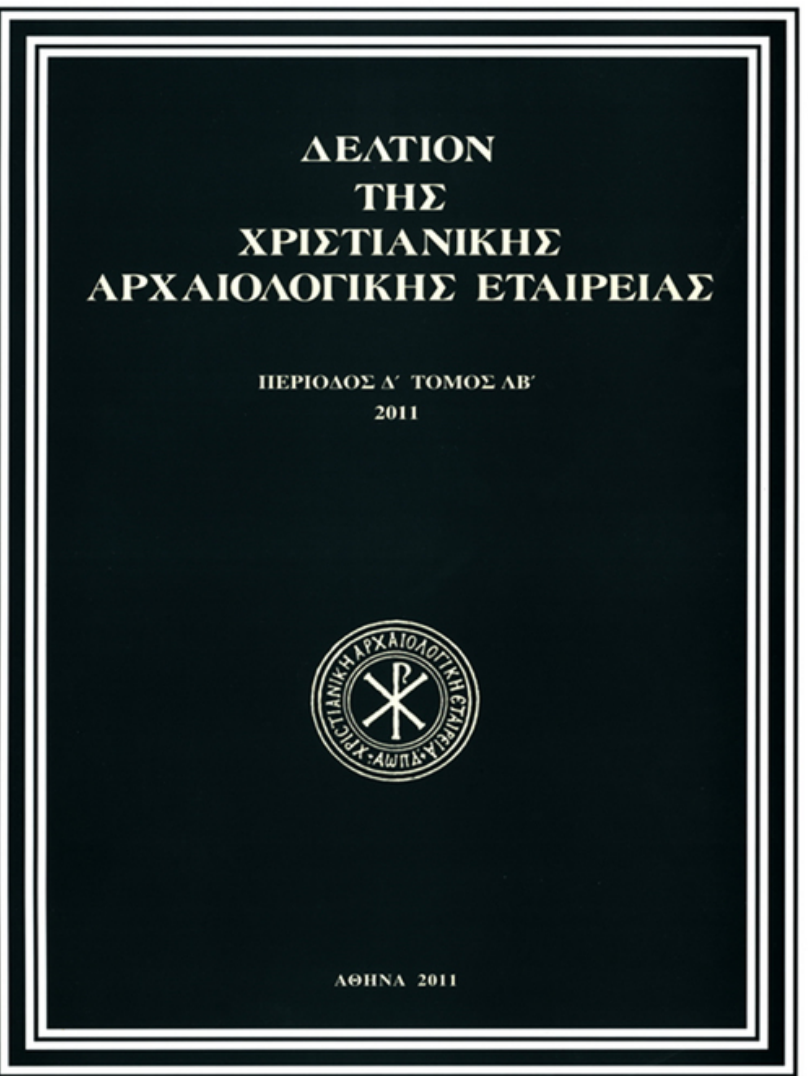

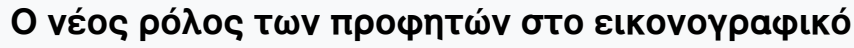

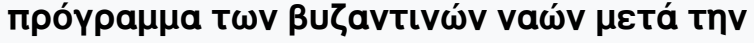

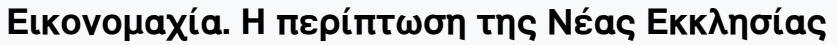
Tokali oтnv Kaпாаסоккía

Natalia TETERIATNIKOV

doi: $\underline{10.12681 / \text { dchae. } 683}$

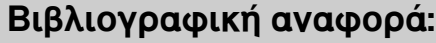

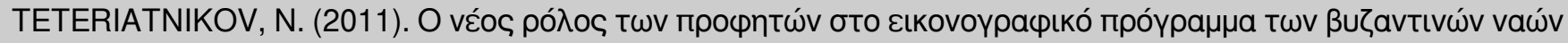

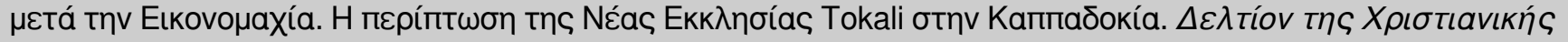

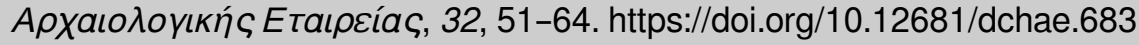




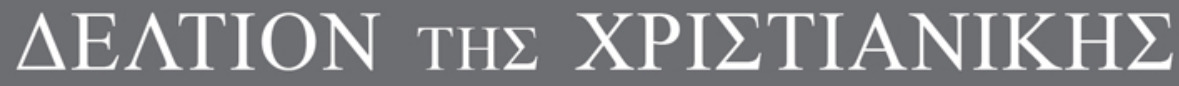 APXAIO $\Lambda$ OГIKH $\Sigma$ ETAIPEIA $\Sigma$}

The New Role of Prophets in Byzantine Church Decoration after Iconoclasm. The Case of the New Tokali Kilise, Cappadocia

Natalia TETERIATNIKOV

$\Delta \varepsilon \lambda \tau$ tíov XAE 32 (2011)• $\Sigma \varepsilon \lambda . ~ 51-64$

A@HNA 2011 


\section{THE NEW ROLE OF PROPHETS IN BYZANTINE CHURCH DECORATION AFTER ICONOCLASM. THE CASE OF THE NEW TOKALI KILISE, CAPPADOCIA*}

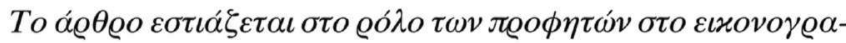

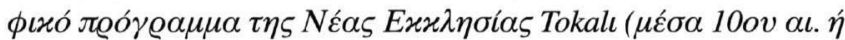

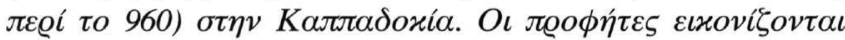

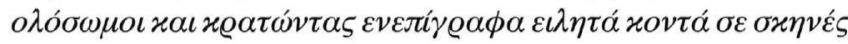

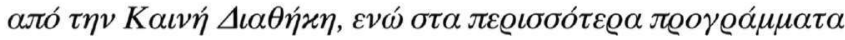

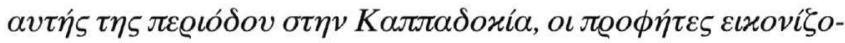

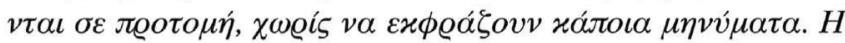

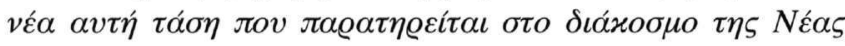

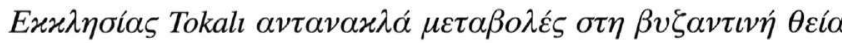

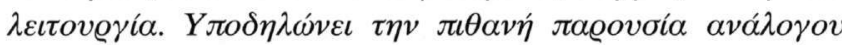

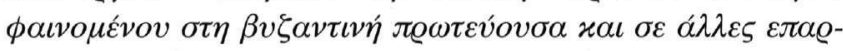

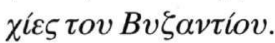

$\mathrm{I}_{\mathrm{n}}$ Byzantine church decoration prophets acted as messengers of the biblical past providing a link between the Old and New Testaments. After Iconoclasm, when dome-type churches came to the fore, prophets often took a prominent position in a dome or a drum ${ }^{1}$. A variety of church plans continued to exist in the Middle Byzantine period. The

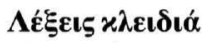 \\ $100 \varsigma \alpha \iota \omega ́ v \alpha \varsigma$.

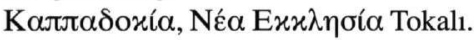

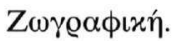 \\ Пஹофиंтє૬.
}

\footnotetext{
* I would like to thank Leslie MacCoull for her valuable suggestions to this article. The photographs are by the auther.

${ }^{1}$ O. Demus, Byzantine Mosaic Decoration, 2nd ed., New York 1976. H.J. Schulz, The Byzantine Liturgy. Symbolic Structure and Faith Expression, New York 1986, esp. 56-62; see also T. F. Mathews, "Religious Organization and Church Architecture", in H. C. Evans and W. D. Wixom (eds), The Glory of Byzantium. Art and Culture of the Middle Byzantine Era, A.D. 843-1261, exhibition catalogue, New York 1997, esp. 31-34. L. Popovich, "Prophets Carrying Texts by Other Authors in Byzantine Painting: Mistake or Intentional Substitution?",

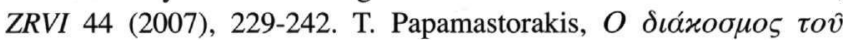

This paper will focus on the role of the prophets in the fresco program of the New Tokalı Kilise (middle of the tenth century or around 960), Cappadocia. Prophets are portrayed standing with inscribed scrolls next to New Testament scenes, whereas the majority of programs in Cappadocia, during this period, display only busts of prophets, without any messages attached. This new trend, observed in the decoration of the New Tokal, is a reflection of changes in Byzantine liturgy. It suggests that such a phenomenon may have existed in the Byzantine capital and other Byzantine provinces.

display and the role of prophets in the decoration of such churches were different, and therefore need to be examined.

This paper will focus on the prophets in the fresco program of the rock-cut church, called the New Tokalı Kilise, in the Göreme valley in the Byzantine province of Cappadocia ${ }^{2}$.

\author{
Keywords \\ 10th. century. \\ Cappadocia, New Tokalı Kilise. \\ Painting. \\ Prophets.
}

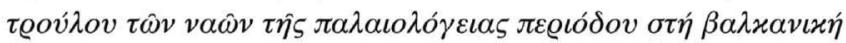

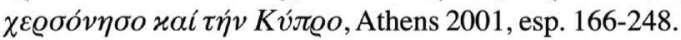

${ }^{2} \mathrm{G}$. de Jerphanion, Une nouvelle province de l'art byzantin. Les églises rupestres de Cappadoce, Paris 1925-42, vol. 2.I, 409-14 (hereafter: Une nouvelle province). Id., "La date des plus récentes peintures de Toqale Kilisse, en Cappadoce", La voix des monuments (Paris and Brussels 1938), 222-36. M. Restle, Byzantine Wall Painting in Asia Minor, Greenwich, Conn., 1967, vol. 1, 111-16; vol. 2, figs 61, 98-99, 115-19. N. Thierry, "Un atelier de peinture du début du Xe siècle en Cappadoce: 1'atelier de l'ancienne église de Tokalı", BAntFr (1971), 170-71; A. Wharton Epstein, Tokall Kilise: Tenth-century Metropolitan Art in Byzantine 
The New Tokalı (middle of the tenth century or around 960$)^{3}$ has one of the best-preserved painted programs from after Iconoclasm. This church has no dome, and thus prophets occupy a location different from those in domed churches. Furthermore, prophets in the New Tokalı have a distinct place and visual characteristics, which makes them different from their depiction in other Cappadocian churches of this period. Here prophets are portrayed standing with inscribed scrolls next to New Testament scenes, whereas the majority of programs in Cappadocia display only busts of prophets in medallions or squares without any messages attached. The only eleventh-century churches such as Elmalı ${ }^{4}$ and Karanlik Kilise $^{5}$ have prophets with inscribed scrolls displayed on arches supporting domes. The selection of prophets in these churches is somewhat similar to that in other Byzantine domed churches. In order to identify the unique role of prophets in the New Tokal1, I will examine their location, their relevance to the New Testament scenes, and their role in the context of the program, as well as the sources.

\section{The display of prophets in the program}

The location of prophets in the New Tokal program relies on the church plan and the selection of New Testament scenes to which the prophets are attached.

The church has a hybrid plan consisting of a transverse nave and single-nave church (Figs 1-2). The transverse nave with three independent sanctuaries was added to an old single-nave church sometime in the middle of the tenth century or around $960^{6}$. The old nave retained its original decoration; the added transverse nave received a new painted program. Considering the plan, the artist displayed three major iconographic subjects on the barrel vault of the transverse nave: the Ascension, the Benediction of the Apostles, and Pentecost. Prophets are depicted next to these iconographic subjects. In addition, two prophets are placed in close proximity to the Crucifixion, which occupies the central apse conch. Scenes from the Life of Christ and images of saints

Cappadocia (DOS 22), Washington D.C., 1986, 6-13, 29-32, with bibliography 4-5, note 2 (hereafter: Tokall Kilise). L. Rodley, Cave Monasteries of Byzantine Cappadocia, Cambridge 1985, 213-222. C. Jolivet-Lévy, Les églises byzantines de Cappadoce: le programme iconographique de l'abside et de ses abords, Paris 1991, 94-108, with bibliography. Ead., La Cappadoce médiévale: images et spiritualité, Paris 2001, 130-31, pl. 30 (hereafter: La Cappadoce médiérale).

${ }^{3}$ Wharton Epstein, Tokalı Kilise, 29-32.

${ }^{4}$ Restle, op.cit., vol. 2, pl. XVIII, figs 160, 161, 167-70; A.-M. Gravgaard, Inscriptions of Old Testament Prophecies in Byzantine Churches,

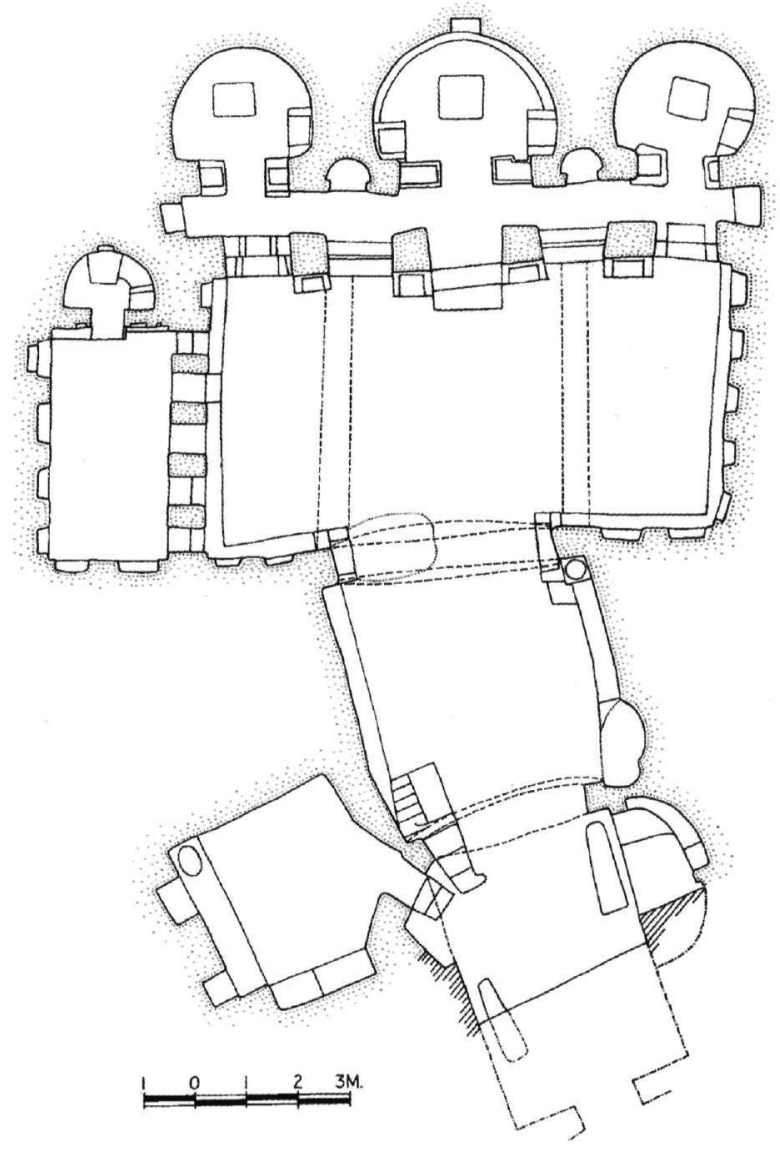

Fig 1. Tokalı Kilise, plan (after Wharton Epstein, Tokalı Kilise, fig. 6).

adorn the walls of the church. Let us examine the relevance of prophets to the above-mentioned New Testament scenes.

\section{The Crucifixion}

Two prophets occupy an important place in close proximity to the Crucifixion, the key subject of the central apse conch

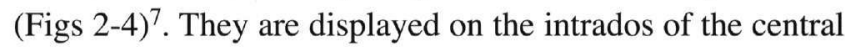

Copenhagen 1979,93 , no. 2 .

${ }^{5}$ Restle, op.cit., vol. 2, pl. XXII, figs 218, 223. Gravgaard, op.cit., 93, no. 3 .

${ }^{6}$ Wharton Epstein, Tokall Kilise, 4-13. Wharton Epstein suggested that the artist of the New Tokalı was familiar with the art of the Byzantine capital of this period (op.cit., 39-44).

7 Jerphanion, Une nouvelle province, vol. 1.2, 345-48. Wharton Epstein, Tokalı Kilise, 73-74, fig. 83. Jolivet-Lévy, La Cappadoce médiévale, 130-31, pl. 30 . 


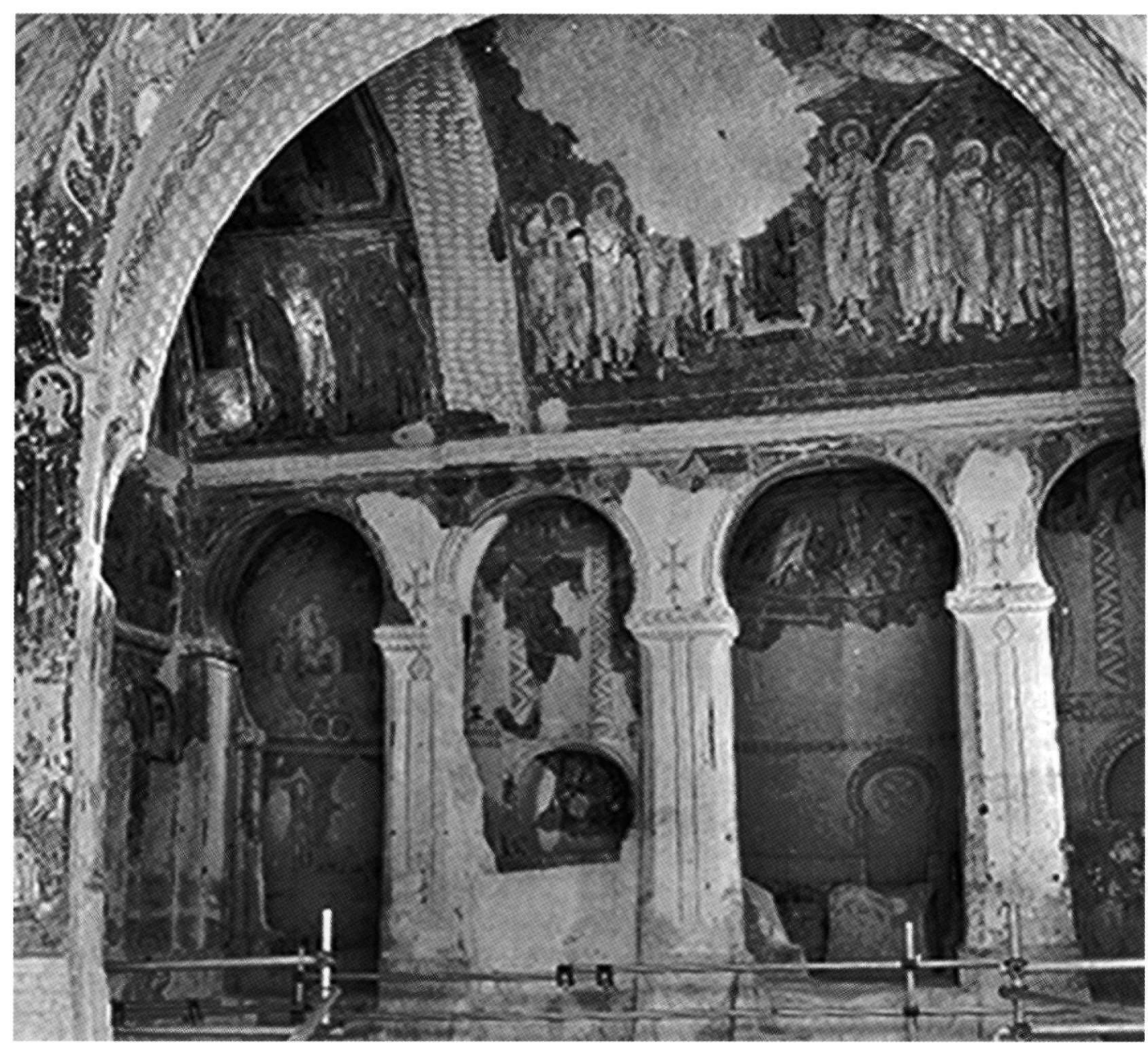

Fig. 2. New Tokalı Church, general view looking east.

arch of the sanctuary screen. This arch faces the central apse where the image of the Crucifixion of Christ flanked by the Crucifixions of the Good and Bad Thieves is depicted. The apex of this arch has an image of an archangel. Below, there are two prophets, Jeremiah and Ezekiel, holding inscribed scrolls. Scholars have recognized their association with the Crucifixion in the central apse ${ }^{8}$. On the left is Jeremiah who points with his right hand in the direction of the Crucifixion of Christ. The scroll in his left hand is inscribed with the text of Jeremiah 11.19: "But I was like a gentle lamb led to the

\footnotetext{
${ }^{8}$ Wharton Epstein, Tokall Kilise, 74, fig. 83. A. D. Kartsonis, Anastasis: The Making of an Image, Princeton 1986, 168-73.

${ }^{9}$ Wharton Epstein, Tokall Kilise, 74, fig. 83. This text is also found in the scroll of a prophet Jeremiah in the fourteenth-century church of the
}

slaughter. I did not know that they devised schemes against me, saying, "Let us destroy the tree with its fruit"9. We find that this text is included in the tenth-century Typikon of the Great Church, in the readings for the sixth hour on Holy Thursday, for the veneration of the Holy Lance ${ }^{10}$. In fact, in the scene of the Crucifixion, the centurion Longinus pierced the side of Christ with a sponge-bearer on the right makes a reference to Holy Saturday when the actual event took place. On the right side of the arch is the prophet Ezekiel. He is depicted frontally, blessing with his right hand toward the

Archangels in Lesnovo. See Papamastorakis, op.cit., 211 and fig. 11 on p. 209.

${ }^{10} \mathrm{~J}$. Mateos, Le typikon de la Grande Église (OCA 165), Rome 1962, vol. 2, 72-73. 
nave. He is holding a scroll in his left hand inscribed with the text of Ezekiel 37.1: "The hand of the Lord was upon me, and he brought me out by the spirit of the Lord, and set me down in the midst of a valley; it was full of dry bones"11. We find this text in the ninth-century Prophetologion also on Holy Thursday ${ }^{12}$, at matins in the Old Testament reading, and on Holy Saturday in the Typikon of the Great Church ${ }^{13}$. The text alludes to the vision of the dead and refers to Christ's death on the cross and resurrection. Thus the texts on the scrolls of both prophets came from the texts recited at vespers during Holy Week, the day when Christ was crucified and the day of his resurrection. The body language of both prophets and the context of the messages they carry emphasize the focal theme of the apse decoration, Christ's Crucifixion.

\section{The Ascension and Benediction of the Apostles}

Christ's Ascension and Benediction of the Apostles are displayed at the center of the vault, and thus they immediately capture the attention of the viewer (Figs 1, 2, and 5) ${ }^{14}$. The east and most visible side of the vault is reserved for the Ascension, whereas the western part of the vault is decorated with the scene of the Benediction of the Apostles. These two scenes are separated from the north and south sides by the relieving arches. Originally the latter displayed figures of prophets, with four prophets on each of the relieving arches framing this vault. No prophets survive near the Benediction of the Apostles. As for the Ascension on the eastern part of the vault, in the 1920s Jerphanion recorded the figure of David at the north arch, and the lower part of the prophet above him ${ }^{15}$. Now only a fragment of David's figure survives. The inscription near his figure, recorded by Jerphanion, reads: "God has gone up with a shout, the Lord with the sound of the trumpet" (Psalm 46.6) and "Make a joyful noise to God, all the earth"
(Psalm 65.1). This psalm was recited during the evening celebration of the pannychis service on the feast of the Ascension in the Typikon of the Great Church ${ }^{16}$. The latter also includes readings for the Benediction of the Apostles. Thus, both the Ascension and Benediction of the Apostles were a part of the feast of the Ascension. Psalm 46.6 is also found in the ninthcentury Triodion-Pentekostarion Koinonikon for the Ascension feast ${ }^{17}$.

No other examples of standing figures of prophets with scrolls found near the scene of the Ascension or Benediction of the Apostles have survived from this period in Cappadocia. Both scenes are found in the Kiliçlar Kilise in Göreme, dated ca. $900^{18}$, and the so-called Pigeon House in Çavuşin, ca. $965^{19}$. However, prophets in these churches are depicted as busts in medallions, the way they are portrayed in many Cappadocian churches of this period. The only known example of a standing figure of a prophet with an inscribed scroll next to these scenes comes from the eleventh-century Homilies of the Life of the Virgin by James the Monk, Biblioteca Apostolica Vaticana, cod. gr. 1162 , fol. $2 \mathrm{v}^{20}$. This illumination shows a domed structure with an upper lunette decorated with the scene of Pentecost. Below and at the center is a scene of the Ascension flanked by two prophets, Isaiah and David, with scrolls (Isaiah 63.1; Psalm 46.6). Significantly, the figure of David and the text of his scroll are similar to the way he is depicted near the scene of the Ascension in the New Tokal1. Since the manuscript Vat. gr. 1162 was attributed to a Constantinopolitan workshop, it suggests a Constantinopolitan model for the prophets' texts in the New Tokalı. Although this manuscript was produced later than the frescoes of the New Tokalı, it shows the same link among the prophet, the text of his scroll, and the reading of the text for the feast of the Ascension as it appears in the Typikon of the Great Church.

\footnotetext{
11 Jerphanion, Une nouvelle province, vol. 1.2, 322, pl. 86. Restle, Byzantine Wall Painting in Asia Minor (n. 2), vol. 2, fig. 117. Wharton Epstein, Tokalı Kilise, 74, fig. 83. Kartsonis, op.cit., 170-71.

${ }_{12}$ C. Høeg, G. Zuntz, eds., Prophetologium I, Fasciculus Quintus: Lectiones Sabbati Sancti, Copenhagen 1962, 429.

${ }^{13}$ Mateos, op.cit., vol. 2, 82-83. For the use of Ezekiel text in scrolls of prophets in Palaeologan churches see Papamastorakis, op.cit. (n. 1), diagram 12 on p. 212 and 214. See also G. Millet, La peinture du Moyen Âge en Yougoslavie (Serbie, Macédoine et Monténégro), Paris 1962, Fasc. III, pl. 66. S. Ćirković, V. Korać, G. Balić, Studenica Monastery, Belgrade 1986, 73. Popovich, "Four Prophet Cycles". op.cit., 291, diagram I.

${ }^{14}$ Jerphanion, Une nouvelle province, vol. 1.2, 350-52, pl. 80, nos 1-2. Wharton Epstein, Tokalt Kilise, 23-27, figs 12-13, 50, 88-92.
}

\footnotetext{
${ }^{15}$ Jerphanion, Une nouvelle province, vol. 1.2, 317. Wharton Epstein, Tokalı Kilise, 76, and fig. 64.

${ }^{16}$ Mateos, op.cit. (n. 10), vol. 2, 126-27.

${ }^{17}$ R. F. Taft, A History of the Liturgy of St. John Chrysostom, vol. 5, The Communion Rites, Rome 2000, 307. Gravgaard, Inscriptions (n. 4), 30. ${ }^{18}$ Restle, op.cit. (n. 2), vol. 2, pl. XXIV, figs 252 and 275. Jolivet-Lévy, La Cappadoce médievale, diagram on p. 289, and fig. 151.

${ }^{19}$ Jerphanion, Une nouvelle province vol. 1, 520-50. N. Thierry, Haut Moyen Âge en Cappadoce. Les églises la région de Çavuşin, Paris 1983, 43-57, Jolivet-Lévy, La Cappadoce médiévale, 70-73, pl. 41.

${ }^{20}$ Evans and Wixom (eds), The Glory of Byzantium (n.1), no. 62, 107109, fig. 62.
} 


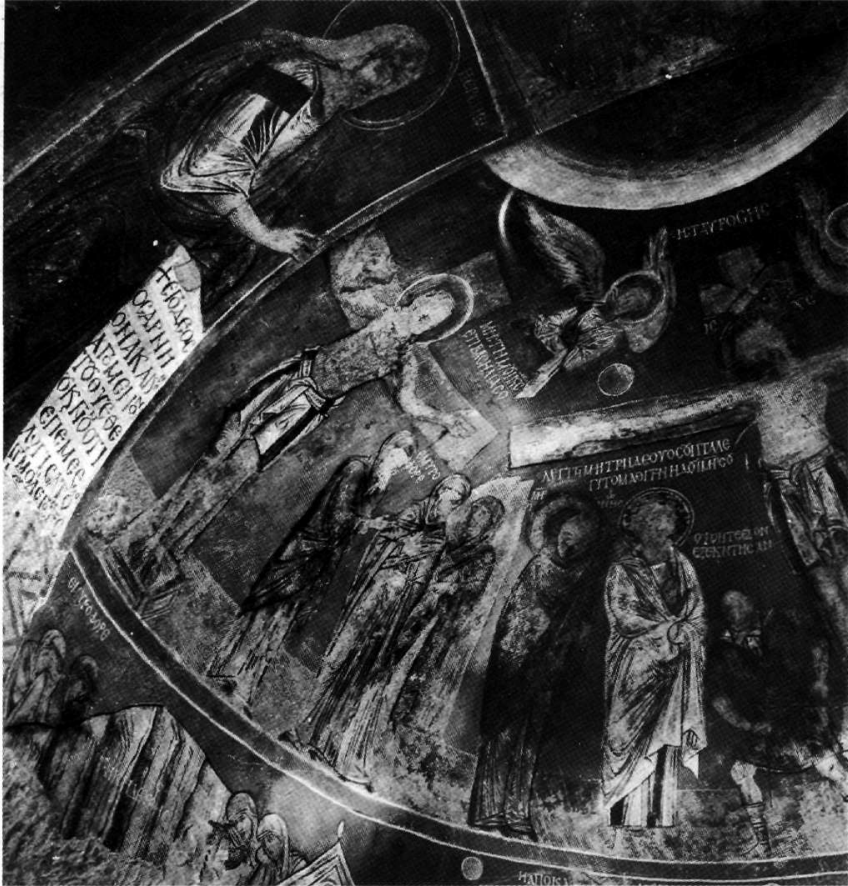

Fig. 3. New Tokalı Church, central apse, conch and arch, north side.

\section{Pentecost}

The Pentecost scene occupies the center of the barrel vault of the south bay (Fig. 6) ${ }^{21}$. It depicts large figures of enthroned apostles seated on both sides of the barrel vault, facing each other, with flames over their heads. Separated by an ornamental band, there are two lower registers on both side of the vault; each represents two scenes relevant to Pentecost. The lower register on the east side of the vault depicts a large figure of the prophet Joel holding an inscribed scroll in front of images of the nations (Fig. 7). They are represented as a group of two kings, with the elder and people in front of the city walls. Behind the city wall, which creates a visual barrier between the scenes, there is a scene of Peter ordaining the first deacons (Fig. 7) 22 . Peter is blessing a group of apostles on his left. He is shown as a larger figure standing in the middle of the group. Joel is even larger than Peter, probably because he was a prophet and thus ranked higher in the hierarchy. Enlarging Joel and Peter's

\footnotetext{
${ }^{21}$ Jerphanion, Une nouvelle province, vol. 1.2, 352-54. Wharton Epstein, Tokalt Kilise, 76, figs 93-97. Jolivet-Lévy, La Cappadoce médiévale, pls 31-33.

22 Jerphanion, Une nouvelle province, vol. 1.2, 355-56. Wharton Epstein, Tokall Kilise, 76, figs 93, 98.
}

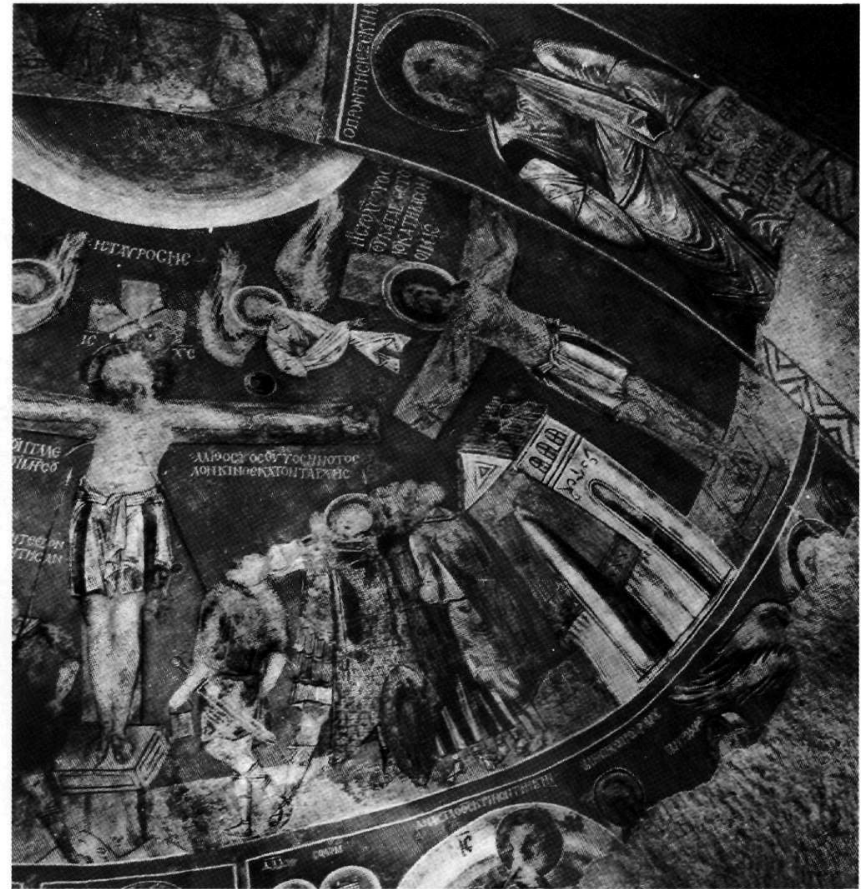

Fig. 4. New Tokalı Church, central apse, conch and arch, south side.

figures, the artist emphasized their significance and connection. Joel's right hand stretches in the direction of the nations but also toward the next scene in which Peter is ordaining the deacons. Visually, Joel approves a New Testament event. K. Corrigan, discussing the Forerunner's gesture in the icon of John the Baptist from Mount Sinai (currently in Kiev); convincingly argued that it represents grace, a sort of previous approval of this later event ${ }^{23}$. Similarly, Joel's image conveys to the public the realization of the Old Testament prophecy in the happening of the New Testament event.

On the opposite, west side of the barrel vault, below the figures of enthroned apostles, there are two scenes including the Mission of the Apostles ${ }^{24}$ and the nations in front of the city walls, followed by a figure of the evangelist Luke holding an inscribed scroll (Fig. 8). In the first scene, the Mission of the Apostles, Peter blesses the apostles. The figures of Peter and Luke in both scenes are much larger than all the other figures. Luke, however, is depicted similarly to the prophet Joel, as a

\footnotetext{
${ }^{23} \mathrm{~K}$. Corrigan, "The Witness of John the Baptist on an Early Byzantine Icon in Kiev", DOP 42 (1988), 3-7, fig. 1.

${ }^{24}$ Jerphanion, Une nouvelle province, vol. 1.2, 356. Wharton Epstein, Tokalı Kilise, 77, fig. 99.
} 


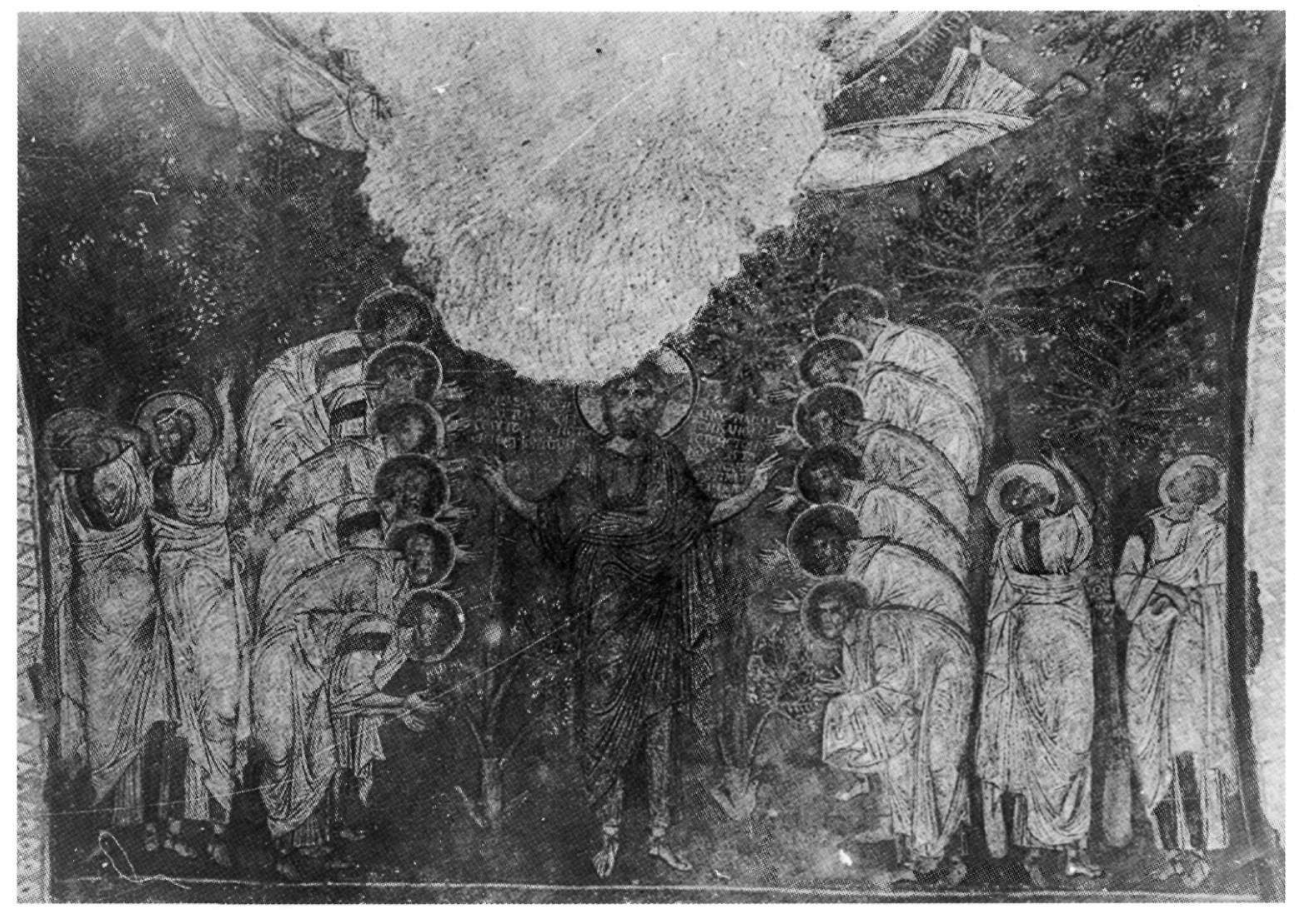

Fig. 5. New Tokalı Church, central bay, barrel vault, west side. Benediction of the Apostles.

larger figure. Both Joel and Luke are shown on the opposite side of the barrel vault. The inclusion of the prophet Joel and the evangelist Luke standing in front of the nations just opposite each other in the south bay is unique to the scene of Pentecost. Both hold inscribed scrolls in their left hands. Joel's inscription on his scroll is a prophecy on the pouring forth of the Spirit. This text is not, however, the one in the book of Joel proper, but from the Acts of the Apostles (Acts 2.17-18), where Joel's quotation (Joel 2.28-29) is cited ${ }^{25}$. The text is prescribed for the reading for the Sunday liturgy on Pentecost. Notably, the evangelist Luke on the opposite side of the vault is depicted as an Old Testament prophet with a scroll in his left hand; the quotation on the scroll comes from the Acts of the Apostles (Acts 2.1 and 1.14; cf Luke $24.49-50)^{26}$. The same citation of this text we find in the abovementioned Typikon of the Great Church for Saturday, the vigil of Pentecost ${ }^{27}$, which is similar to the text on Luke's scroll in the New Tokall. The Typikon of the Great Church includes the texts from the Acts of the Apostles ${ }^{28}$. The texts on the scrolls of both Joel and Luke were evidently taken from the church service on

\footnotetext{
${ }^{25}$ Wharton Epstein, Tokalı Kilise, 76. Popović indicates that prophets' scrolls often have texts from other authors. See Popovich, op.cit. (n. 1), 231-42.

${ }^{26} \mathrm{Ibid}$.
}

the day of Pentecost. Both Joel and Luke next to the images of the nations are part of the Pentecost program. The scenes of Peter ordaining new deacons and the Mission of the Apostles were added on both sides of the vault to further enhance the apostolic role of the New Testament. Juxtaposing the prophet Joel and the evangelist Luke in the Pentecost program makes visible to the public the fulfillment of the Old in the New Testament.

An examination of the prophets' locations, their bodily gestures, and the texts on their scrolls suggests that the author of the program used images of prophets and their texts to further highlight the high-ranking feasts of the calendar year, and to send messages to the public about Christ's death, Resurrection, and Ascension, followed by the sending of the Holy Spirit on Pentecost. These feasts were connected in this decorative program to show the continuity of the New Testament events commemorating Christ's death.

The Crucifixion was commemorated on Good Friday. The Ascension, forty days after his Resurrection, was one of the major feasts of the liturgical year, accompanied by processions,

\footnotetext{
${ }^{27}$ Mateos, Le typikon de la Grande Église (n.10), vol. 2, 137-39.

${ }^{28}$ The Typikon includes readings from the Acts and Joel, but the passages are different.
} 


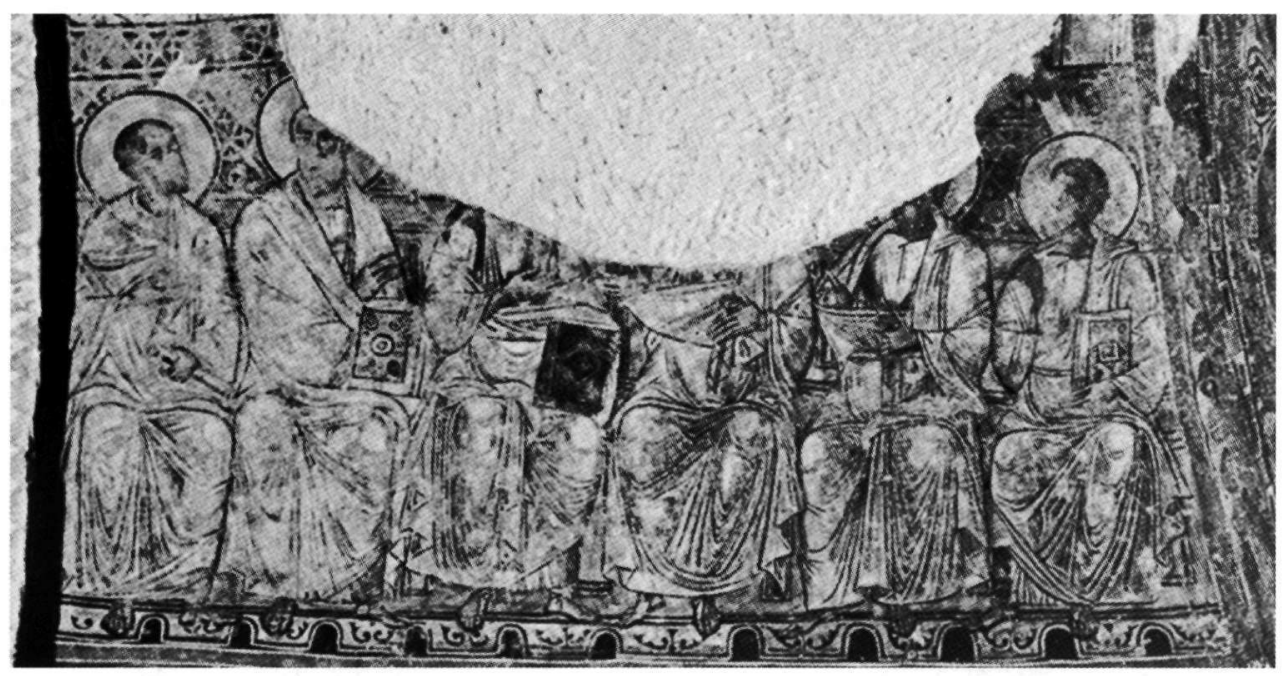

Fig. 6. New Tokalı Church, south bay, barrel vault, south side. The Pentecost.

especially in Constantinople ${ }^{29}$ and its provinces. It also emphasizes the apostolic role of the church, which is expressed in the joint scene of the Ascension and the Benediction of the Apostles conjoined with Pentecost. The emphasis on the scenes of Christ's death and prophecies related to it may reflect the function of the New Tokalı. It has been suggested that the Tokalı church was used for the commemoration of the dead ${ }^{30}$.

\section{Prophets and New Testament scenes in Byzantine church}

\section{Decoration: the sources}

Representations of prophets near New Testament scenes are found in few instances, probably owing to the destruction of Byzantine monuments over time.

One case is the eleventh-century painted decoration in the church of the monastery of St. Chrysostomos at Koutsovendis, Cyprus $^{31}$. The decorative program of this church is in a fragmentary state of preservation, and therefore only two prophets in connection with the New Testament narrative have survived.
One is the prophet Ezekiel, who is juxtaposed with the scene of the Anastasis. Ezekiel is shown standing on the east face of the southwest pier. His scroll has the text of Ezekiel 37.12-13 with slight inversion: "Thus saith the Lord: Behold, I will open your graves and bring you up out of your graves." The latter refers to the resurrection of the dead, and to the scene of the Anastasis, displayed on the south wall. The text of the prophet is included in the Old Testament reading for Holy Saturday in the abovementioned Prophetologion ${ }^{32}$. The second scene depicts the Betrayal of Christ on the north wall. The left part of the scene is lost. On the right side there is the standing figure of a prophet with his scroll. There is no inscription to identify the prophet, and the text of his scroll is gone. Thus it is difficult to understand the original messages of the prophets embedded in the program. It is clear, however, that the author's intention was to bring the prophet and the New Testament event together in a similar way as was done in the New Tokalı.

Another case comes from the ninth or tenth-century frescoes of the Deir al-Surian monastery church, Wadi al-Natrun, Egypt ${ }^{33}$.
29 J. F. Baldovin, The Urban Character of Christian Worship: The Origins, Development, and Meaning of Stational Liturgy (OCA 228), Rome 1987, 182-83, 194, 199, 210, 213, 215.

30 Jerphanion, Une nouvelle province, vol. 1.2, 322, pl. 86. Restle, op.cit. (n. 2), vol. 2, fig. 117. Wharton Epstein, Tokalı Kilise, 74, fig. 83. Kartsonis, Anastasis (n. 8), 170-71.

${ }^{31}$ C. Mango, with the collaboration of E. J. W. Hawkins and S. Boyd, "The Monastery of St. Chrysostomos at Koutsovendis (Cyprus) and its Wall Paintings, Part I: Description”, DOP 44 (1990), 82-85, figs 98, 104 and 105.
${ }^{32}$ Gravgaard, Inscriptions (n. 4), 41, no. 64. Høeg and Zuntz, Prophetologium (n.12), 429.

${ }^{33}$ P. Van Moorsel, "A Brief Description of the Annunciation Discovered in 1991 at Deir es Sourian," CahArch 43 (1995), 118-24, and figs 1-8. M. Wuttmann, "Circonstances de la découverte de la peinture de l'Annonciation dans la concque ouest de l'église de la Verge au Deir alSouriani et observations techniques", ibid., 125-128. K. C. Innemée, "Deir al-Sourian. The Annunciation as Part of a Cycle?", ibid., 129-132. $\mathrm{N}$. Thierry and $\mathrm{H}$. Kessler attributed the frescoes from the eighth to the tenth centuries: N. Thierry, 'L'Annonciation de Deir es Souriani, 


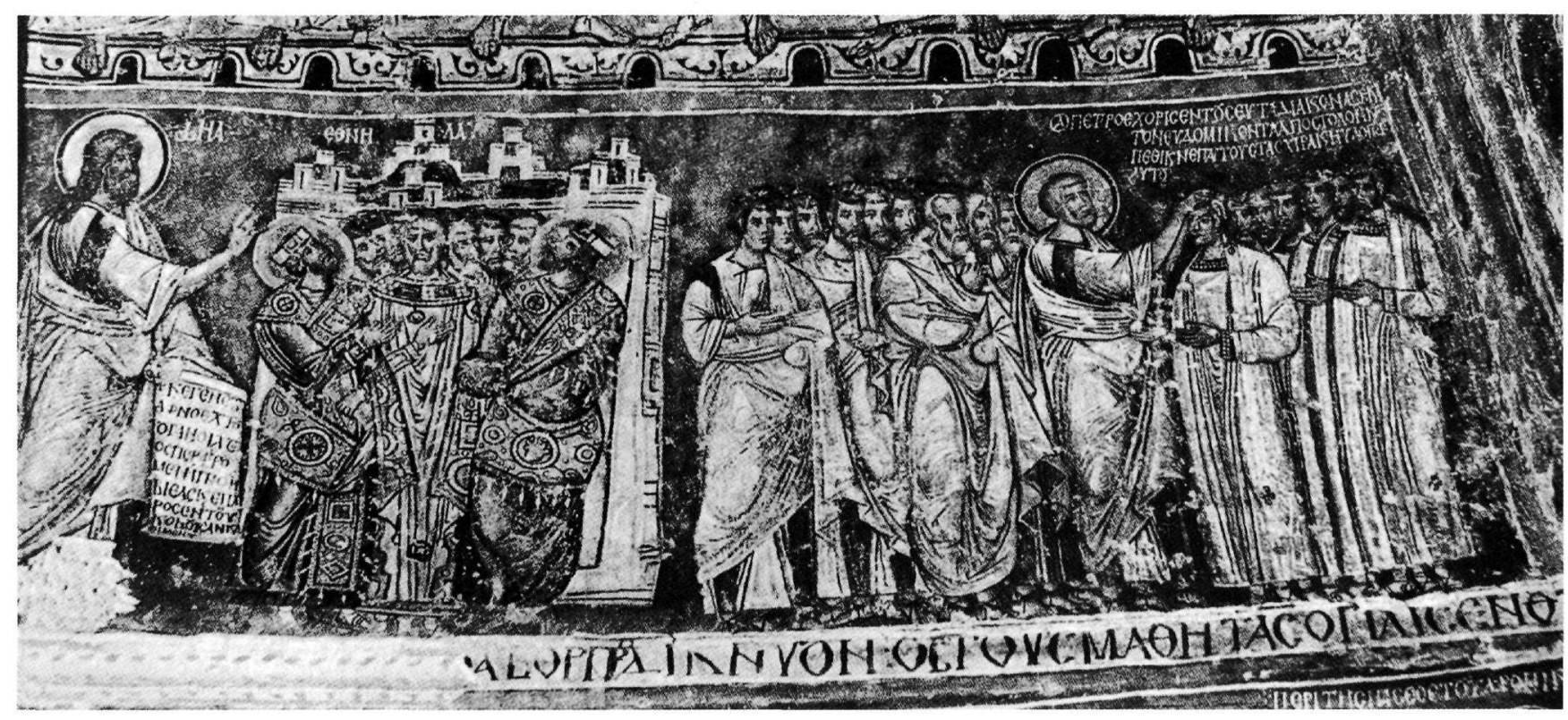

Fig. 7. New Tokalı Church, south bay, barrel vault, east side. Joel and the Nations and Peter Ordaining the First Deacons.

Here the western semi-dome of the naos displays the scene of the Annunciation. It represents Mary enthroned with Gabriel on her left, and two prophets on each side of the scene: Isaiah, Moses, Ezekiel, and Daniel. Three prophets gesture toward Mary and Gabriel. Only Daniel on the far right has his arm to his chest. All prophets hold inscribed scrolls in their hands ${ }^{34}$. The texts on the scroll of Moses include Exodus 3.2b, prefiguring the Virgin in the Burning Bush. The text of Isaiah 7.14: "God with us," is about the birth of Christ..$^{35}$ Ezekiel 44: 2 is a reference to the Virgin as the shut gate. ${ }^{36}$ Daniel's text (Daniel 2.34) on his scroll prefigures the Virgin Birth in the stone cut out from the mountain without human hands ${ }^{37}$. Lucy-Anne Hunt pointed out that the prophets' texts referred to the typology of the Virgin and the coming of Christ to the world ${ }^{38}$. The prophets' gestures as

Recherches typologiques", ibid., 133-40. H. Kessler "Byzantine Art and the West. Forty Years after the Athens Exhibition and Dumbarton Oaks Symposium", in A. C. Quintavalle (ed.), Medioevo mediterraneo: l'Occidente, Bysanzio e l'Islam, Milan 2007, 57-72. Lucy-Anne Hunt and Tania Velmans date the frescoes to the twelfth century: L-A. Hunt, "The Newly Discovered Wallpainting of the Annunciation at Dayr alSuryān", ibid., 147-52. Ead., "The Fine Incense of Virginity: a Late Twelfth Century Wallpainting of the Annunciation at the Monastery of the Syrians, Egypt”, BMGS 19 (1995), 182-212, figs 1-20. T. Velmans, "Quelques traits significatifs du style dans l'Annonciation au Monastère des Syriens", CahArch 43 (1995), 141-45.

${ }^{34}$ For the use of this text in the churches of Palaeologan period see Papamastorakis, op.cit. (n. 1), 183. well as their texts were deliberate pointers to the coming of Christ and the role of the Virgin.

The examination of the preserved data shows that the New Tokalı presents the earliest example of the depiction of prophets next to New Testament scenes in church decoration after Iconoclasm. The author of its program incorporated prophets together with New Testament scenes in a sophisticated way, raising the question of where he got such an idea. Why do the texts of the prophets' scrolls have the same quotations as in the Typikon of the Great Church or Propheto-logion? To answer these questions it is important to identify two different modes in the depiction of prophets in Cappadocia: the medallion images of prophets and the standing figures with inscribed scrolls. As stated above, during the above-mentioned period Cap-

\footnotetext{
${ }^{35}$ This text is found in the churches: St. Nicholas in Monemvasia, Parigoritissa in Arta, Peribleptos, Mistra, St. Nicholas tis Stegis in Cyprus, St. Nicholas in Curtea de Argeş, Romania, Church of the Archangels, Lesnovo in Former Yugoslavic Republic of Macedonia, and church of the Virgin, Nova Pavlica in Serbia. See Papamastorakis, op.cit. (n. 1), esp. 204-6.

36 This text is found in the church of Panagia Parigoritissa in Arta, Markov Manastir, and Ljubostinja. See Papamastorakis, op.cit. (n. 1), 214-15, with bibliography on p. 215.

${ }^{37}$ This text is found in St. Nicholas tis Stegis, Cyprus, and Nova Pavlica in Serbia. See Papamastorakis, op.cit. (n. 1), 217 with bibliography on p. 217, n. 332 .

${ }^{38}$ Hunt, "The Newly Discovered Wallpainting”, op.cit., 150.
} 


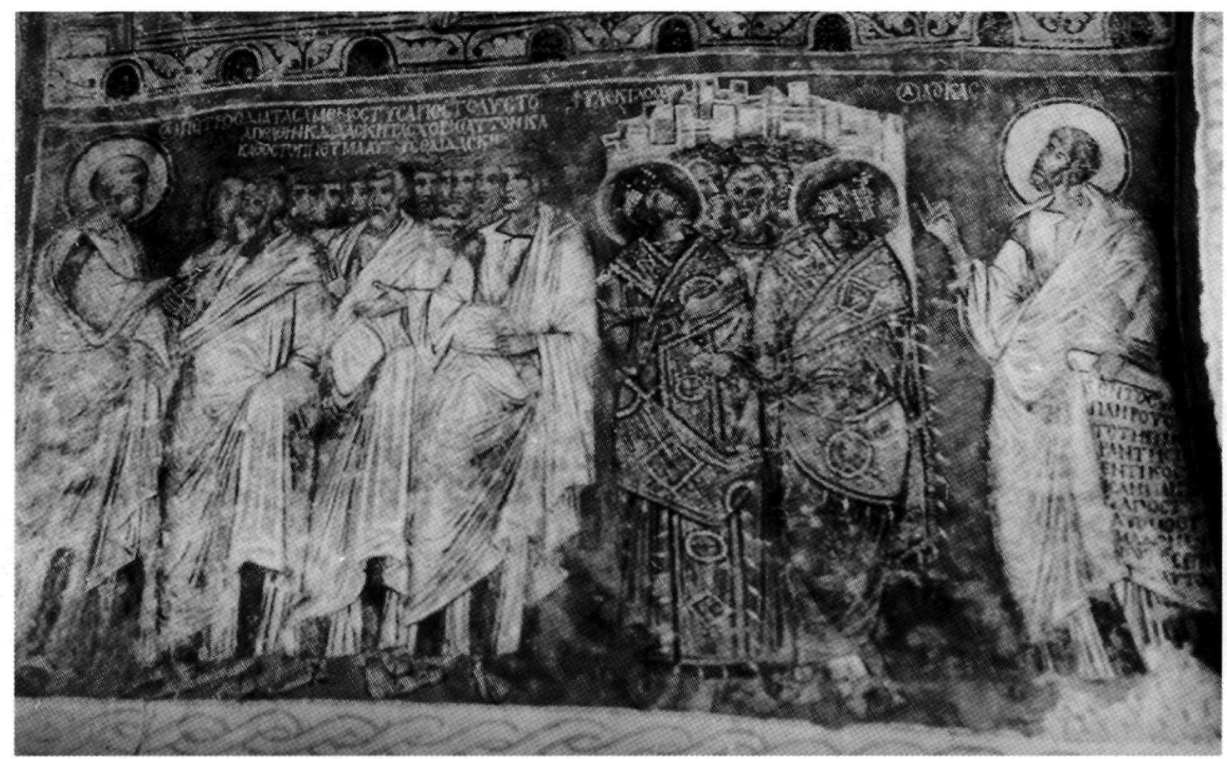

Fig. 8. New Tokalı Church, south bay, barrel vault, west side. Peter and the Mission of the Apostles and Luke and the Nations.

padocian church murals display portraits of prophets in medallions in the intrados of arches or church vaults. Examples can be seen in the ninth- and tenth-century churches such as the Old Tokalı Kilise ${ }^{39}$ and El Nazar ${ }^{40}$, both in Göreme, the Pigeon House in Çavuşinn ${ }^{41}$, St. Barbara in Soğanl ${ }^{42}$, and many others (Fig. 9). In these churches, inscriptions including prophets' names are usually enclosed in medallions or, in some cases, squares accompany busts or half-length figures of prophets.

Medallion images of prophets are widely found in the art of this period, especially in ninth- and tenth-century manuscripts such as the Sacra Parallela in Milan ${ }^{43}$; Turin, Biblioteca Nazionale, cod. B I. $2^{44}$; and others. This mode of depicting busts of prophets in medallions was similar to other holy

\footnotetext{
39 Jolivet-Lévy, La Cappadoce médiévale, fig. 13. Hunt, "The Fine Incense of Virginity", op.cit., 182-212.

40 Jolivet-Lévy, La Cappadoce médiévale, figs 45 and 46.

${ }^{41}$ Ibid., fig. 41.

42 Jolivet-Lévy, La Cappadoce médiévale, pls 88-90.

${ }^{43}$ K. Weitzmann, The Miniatures of the Sacra Parallela, Parisinus Graecus 923, Princeton 1979, 133-60, pls LI-LII, LIV, LVI-LVIII, LXI-LXXVIII.

44 J. Lowden, Illuminated Prophet Books: A Study of Byzantine Manuscripts of the Major and Minor Prophets, University Park and London 1988, 14-22, 111-12, with bibliography on p. 112, figs 16 and 17. Papamastorakis, op.cit. (n. 1), esp. 173-74.

${ }^{45}$ Corrigan, "The Witness of John the Baptist" op.cit. (n. 23), 10.
}

images from the early Byzantine period. Studying the medallion images of Christ and the Virgin in the seventh-century icon of John the Baptist from Sinai, Corrigan pointed out that such images were probably inspired by medallion-like circular imperial portraits at the top of consular diptychs ${ }^{45}$. During the sixth and seventh centuries many medallion images already existed in different media. For example, medallion icons painted on wood have survived from this period, as, for example, three medallion icons of Christ, Virgin and archangel from the Coptic Museum, Cairo ${ }^{46}$. Prophets in medallions were already incorporated into decoration of sixthand seventh-century churches, as is evident in the wall paintings of the Monastery of Apollo, Bawit ${ }^{47}$, or in the apse mosaic in St. Catherine's Monastery, $\mathrm{Sinai}^{48}$. They are gener-

\footnotetext{
${ }^{46} \mathrm{~J}$. Georg and Herzog zu Sachsen, Neue Streifzüge durch die Kirchen und Klöster Ägyptens, Leipzig 1930, 50-51, fig. 14. For icon of Christ see: M. Rassart-Debergh, "De l'icone päenne et l'icone chrétienne", Le Monde Copte 18 (1990), 63-65, figs 24-26. P. P. V. van Morsel et al. (eds), Catalogue génerale du Museé Copte: The Icons, Cairo 1994, 13, 4, cat. nos 6 and 7, pls 2 c, d. Z. Skalova, Icons of the Nile Valley, London 2003, 167, figs A, B, C.

${ }^{47}$ M. J. Clédat, Le monastère et la nécropole de Baouît, Mémoires publiés par les membres de l'Institut français, d'archéologie orientale du Caire 12 (1904), pl. XXXIII.

${ }^{48}$ K. Weitzmann, "Mosaics", in K.A. Manafis (ed.), Sinai. Treasures of the Monastery of Saint Catherine, Athens 1990, 61-68, and pls on pp. 74-75, figs 12-14, 19. Papamastorakis, op.cit. (n. 1), 108.
} 


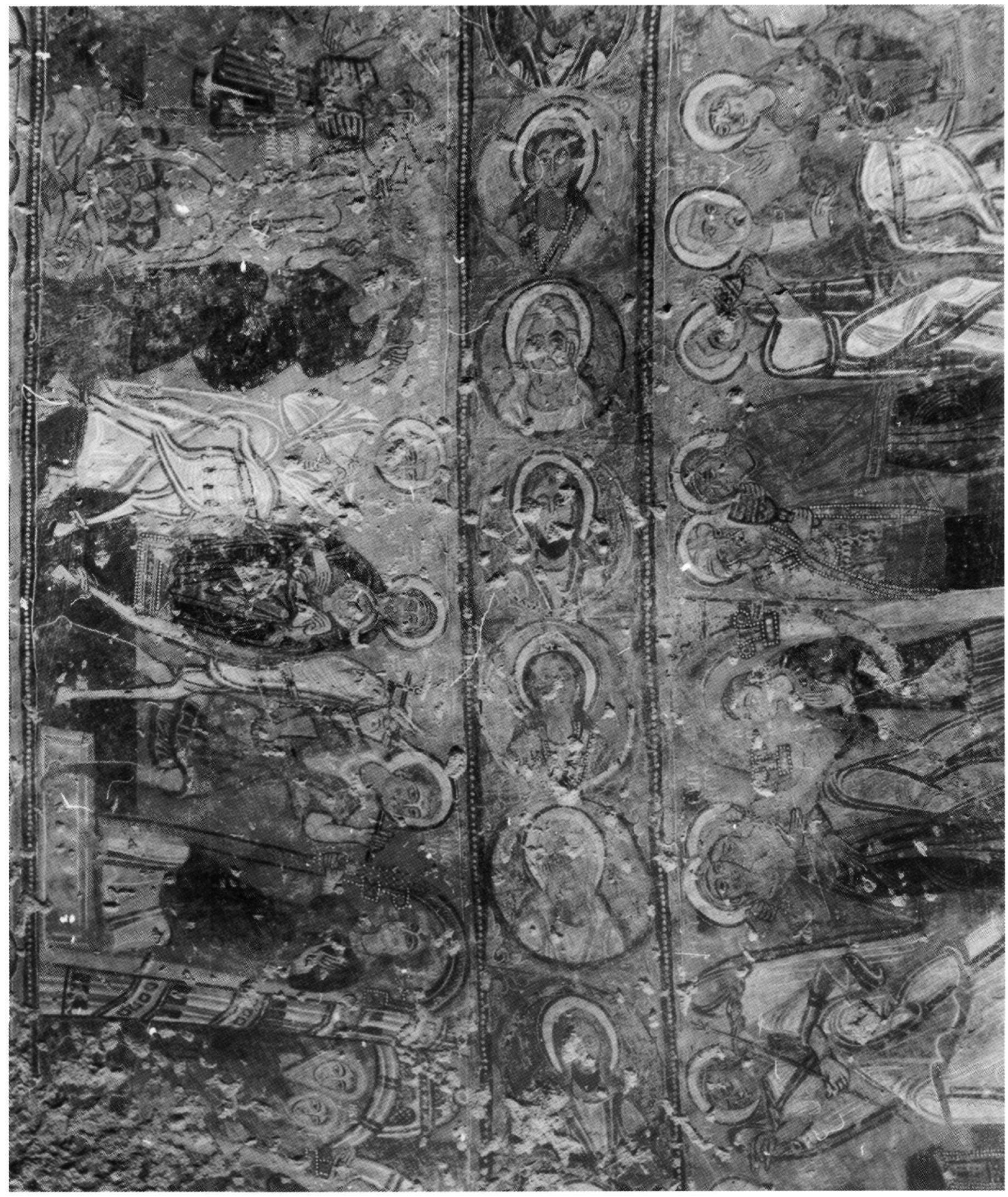

Fig. 9. Old Tokalı Church, vault, center. Prophets in medallions. 
ally presented as Old Testament messengers of the New Testament events, and they are usually depicted on the walls of these churches. After Iconoclasm, many churches in Cappadocia continue to have barrel-vault ceilings. In these churches, medallion images of prophets were placed either around the triumphal arch or in a cross at the center of the barrel vault (Fig. 9).

The New Tokalı presents another mode of depicting prophets: standing prophets with inscribed scrolls, which is unique in Cappadocia of this period. The model for this type of prophets and their texts should come from a different tradition. In order to understand the novelty of portraying prophets next to New Testament scenes in the New Tokalı and their later use in other churches mentioned above, it is necessary to investigate when the alliance of a prophet with a New Testament event occurred in Byzantine art and why.

Representations of prophets with inscribed scrolls in church decoration are known from late antiquity. They appeared in the third-century frescoes of the Dura Europos synagogue ${ }^{49}$, sixth-century churches of Ravenna such as San Vitale ${ }^{50}$, the Baptistery of the Orthodox ${ }^{51}$, or Sant' Apollinare Nuovo ${ }^{52}$. Prophets in these churches hold scrolls with both hands, similar to the prophet Jeremiah in the synagogue of Dura Europos $^{53}$. These prophets' scrolls are not legible. Prophets holding inscribed scrolls with clear and specific quotations are found, however, in various media in the Christian East. Two icons from Sinai, dating to the sixth or seventh century, show standing figures of prophets. One depicts the prophet Elijah holding an inscribed scroll ${ }^{54}$. Another icon, already mentioned above, is that of John the Baptist from Mount Sinai (currently in Kiev), a New Testament prophet, who is also depicted similarly holding a scroll prophesying the coming of
Christ $^{55}$. Similar representations of prophets with open scrolls are found in the church decoration of sixth-century Coptic churches in Egypt, for instance chapels in the monastery of Apollo, Bawit ${ }^{56}$, Karm al-Ahbariya, near Alexandria ${ }^{57}$, or the church of the Red Monastery, near Sohag ${ }^{58}$.

Images of prophets together with New Testament scenes also appeared during this period as can be seen in two manuscript illuminations: the sixth-century Rossano ${ }^{59}$ and Synope Gospels ${ }^{60}$. In both manuscripts, prophets are shown as half-length figures above long rectangular scrolls, which resemble posters. In the Rossano Gospels, prophets gesture toward New Testament scenes which are displayed above them. In the Sinope Gospels prophets flank a singular New Testament scene. The quotations on their scrolls are mostly psalms and Old Testament passages evoking the New Testament events. These quotations may reflect their usage in a contemporary liturgy. But it is difficult to know where the models for these images of prophets and the texts of their scrolls came from.

According to John Lowden's study, the surviving illustrated prophet books date from the middle of the tenth century ${ }^{61}$. Standing figures of prophets are found in an illustrated sixthor seventh-century Syriac Bible, Paris, Ms. Syr. 341, fol. $179 \mathrm{r}^{62}$. As Lowden pointed out, it is not a prophet book, but may be a reflection of a type of book which existed in Byzantium. The presence of prophets with inscribed scrolls in different media in the early Byzantine period in the Christian East suggests that illustrations of prophets with inscribed scrolls went beyond book illuminations.

Very few monumental decorations have survived from the ninth century in Constantinople and the Byzantine provinces. The earliest example of full-length figure prophets with inscribed scrolls is known from the mosaic decoration in the
49 K. Weitzmann and H. L. Kessler, The Frescoes of the Dura Synagogue and Christian Art (DOS 28), Washington, D.C. 1990, 130, figs $175,193$.

${ }^{50}$ F. W. Deichmann, Frühchristliche Bauten und Mosaiken von Ravenna, Baden-Baden 1958, figs 313, 321, 335.

${ }^{51}$ Ibid., figs 72-73, 76-77.

${ }^{52}$ Ibid., figs 100-107, 141, 146.

${ }^{53}$ Weitzmann and Kessler, op.cit., 130, figs 175, 193.

${ }^{54} \mathrm{~K}$. Weitzmann, The Monastery of Saint Catherine at Mount Sinai: The Icons, vol. 1: From the Sixth to the Tenth Century, Princeton 1976, 32, 42-43, pls XIV, XIV(a).

55 Ibid., 32-35, pl. XIV, B.II. Corrigan, "The Witness of John the Baptist”, op.cit. (n. 23), 1-11, fig. 1.

${ }^{56}$ Clédat, op.cit., pl. XXXIII.

57 B. Brenk, Spätantike und Frühes Christentum, Propyläen Kunstgeschichte Suppl. Bd. 1, 1977, 247, 252, no. 288a, fig. 288a. H. Belting,
Bild und Kult, Munich 1990, 103, fig. 38. J. Witte-Orr, Die Wandmalereien von al-Ahbariya: Malereien des späten 6. Jahrhunderts aus der Umgebung Alexandrias (dissertation of Rheinischen Friedrich-WilhelmsUniversität zu Bonn, 1993), 104-31.

${ }^{58}$ E. White and E. S. Bolman, "Chromatic Brilliance at the Red Monastery Church", Bulletin of the ARCE 186 (2004), figs 1, 6, 7.

${ }^{59}$ W. C. Loerke, The Rossano Gospels: The Miniatures, Rome and Graz 1987, esp. 114-20.

${ }^{60} \mathrm{H}$. A. Omont, Miniatures des plus anciens manuscrits grecs de la Bibliothèque nationale du VIe au XIVe siècle, Paris 1929, 2, pls A and B. G. Millet, Iconographie de l'évangele, Paris 1916, 10-11. G. Muñoz, $l l$ codice purpureo di Rossano e il frammento sinopenze, Rome 1907. A. Grabar, Les peintures de l'évangeliaire de Sinope, Paris 1948, 7-26, pls I-V. ${ }^{61}$ Lowden, Illuminated Prophet Books (n. 44), 83.

${ }^{62}$ Ibid., 89-90, fig. 118. 
nave of Hagia Sophia, Constantinople ${ }^{63}$. Prophets were displayed in the tympana of the central nave, as is known from the Fossati drawings. The reconstruction drawing of the mosaics of the north and south tympana, published by Cyril Mango, demonstrates that the new scheme of images was introduced to the naos of Hagia Sophia after Iconoclasm. Hagia Sophia's mosaics have been dated to the last decades of the ninth century or the first decade of the tenth century. Four major prophets, Jeremiah, Isaiah, Ezekiel, and probably David, large in size, are depicted in the corners of the north and south tympana. They hold scrolls and gesture toward the dome and the apse where the image of the Virgin is represented. The texts on their scrolls are found in the Typicon of the Great Church for vespers of December 24, the day before Christmas $^{64}$. Unfortunately, no other murals of this period survive from Constantinople. Some information about these programs can be extracted from contemporary ekphraseis. Patriarch Photius, for instance, describes the decoration of the "New Church" built by Basil I, where he mentioned among other images "A choir of apostles and martyrs, yea, of prophets, too, and patriarchs fill and beautify of the whole church with their images" 65 . Photius did not tell us, however, where and how the prophets were depicted.

Although information is limited, it is clear that prophets acquired a special role in decorative programs after Iconoclasm, as seen in the New Tokalı Kilise and Hagia Sophia. In both churches the choice of prophets depended on the specific concept chosen by the commissioners of the programs. In Hagia Sophia the prophets' message was to praise God and the Virgin and to celebrate the Incarnation of Christ similar to the Deir al-Surian wall-painting. In the case of the New Tokalı, prophets manifest Christ's death on the cross, his Ascension to heaven, and Pentecost - subjects suitable for a funerary chapel. In both buildings, the central cathedral of the empire and the monastery church in Cappadocia, prophets are depicted in the naos where they could be easily seen by the faithful. After Iconoclasm, incorporation of full-length figures of prophets with inscribed scrolls into church decoration most likely came from the Byzantine capital, as the usage of the texts from the Typikon of the Great Church and Prophetologion and the illustrated prophet books suggests.

\section{The place of prophets in the liturgy}

Though no Cappadocian Typika have survived, we may infer their similar use in church services both in Constantinople and Cappadocia. Is it indeed possible that the reading of the texts from the prophets was similar in Constantinople and Cappadocia at that time?

Pentkovskii's study shows that in the second part of the seventh century a new element was introduced into the Jerusalem liturgy, a canon consisting of a selection of biblical texts from the Jerusalem Psalter ${ }^{66}$. Soon after that in Jerusalem, a new lectionary and troparion were created and accepted in the monasteries of St. Saba, St. Theodosius, and others. It is possible that the appearance of these liturgical books with prophets' readings stimulated Christian iconography in the Christian East. Therefore we find representation of prophets with inscribed scrolls on some Sinai icons dating to the seventh and eighth centuries. Similarly, prophets appear in wall-paintings of Coptic churches in Egypt.

Reforms in the liturgy took place during Iconoclasm, bringing further developments. The Iconoclasts modernized the liturgy and made it contemporary. They focused specifically on Christ's Eucharist and the New Testament. That is why after Iconoclasm these changes were already a part of the liturgy. In the middle of the eighth century these changes were reflected in the creation of new lectionaries and a new Euchologion. The new lectionaries contained only New Testament texts, with Old Testament texts separately in the Prophetologion. On feast days readings from the prophets were transferred to vespers. During the Eucharistic liturgy only New Testament texts were read. These new reforms were incorporated into the Typikon of the Great Church and other liturgical books, which prescribed specifically when Old and New Testament texts were read 67 .

\footnotetext{
${ }^{63}$ N. Teteriatnikov, "Hagia Sophia, Constantinople: Religious Images and their Functional Context after Iconoclasm", Zograph 30 (20042005), 9-19, esp. 14-15, and figs 10 and 11. R. Cormack and E. J. W. Hawkins, "The Mosaics of St. Sophia at Istanbul: The Rooms above the Southwest Vestibule and Ramp", DOP 31 (1977), 228. Papamastorakis (n. 1), esp. 176-77, 274.

${ }^{64}$ Teteriatnikov, op.cit., esp. 14-15.

${ }^{65}$ C. Mango, The Homilies of Photius, Patriarch of Constantinople, Cambridge, Mass. 1958, 187-88.
}

${ }^{66}$ A. Pentkovskii, "Konstantinopol'ski i Erusalimski bogosluzhebni ustav", ZMP 4 (2001), 71-72. Cf. M. Aranz, Les grandes étapes de la liturgie byzantine: Palestine-Byzance-Russie, Rome 1976, 43-72. N. Egender, "La formation et l'influence du Typikon liturgique de SaintSabas", in J. Patrich (ed.), The Sabaite Heritage in the Orthodox Church from the Fifth Century to the Present, Leuven 2001, 209-16.

${ }^{67}$ For the use of prophets texts in the liturgy and middle and late Byzantine church decoration see Papamastorakis, op.cit. (n. 1), esp. $166-68,263-83$. 
Høeg and Zuntz thought to determine the origin of the Prophetologion $^{68}$ - a book which most likely affected the selection of prophets' texts for the ninth- and tenth-century decorative programs in Constantinople and its provinces ${ }^{69}$. The Prophetologion is a collection of lessons read during Lent on the first four days of the week at matins and at the Liturgy of the Presanctified in the evening. The Prophetologion reflected the reforms in the Byzantine liturgy made by the end of the eighth century, and especially affected the lessons in the Liturgy of the Presanctified. The Prophetologion was created in Constantinople and grew out of the usage in the patriarchal church of the capital. Hoeg and Zuntz proposed that the Prophetologion was created in the Studion monastery. Both the Typikon of the Great Church and the Prophetologion were meant to be used in Hagia Sophia. Once it was created, copies of the Prophetologion were made and widely disseminated by the metropolitan scriptoria in the provinces. This was done for the sake of the uniformity of the Orthodox liturgy. That is probably why we find that the texts of prophets in the Tokalı Kilise match most of their usage in the feast days in the Typikon of the Great Church. Since the quotations of the prophets in the Tokalı Kilise matches the Typikon of the Great Church and Prophetologion, it is possible that the commissioner of the program used both texts as sources for the prophets' texts in the decoration.

\section{Conclusion}

After Iconoclasm there was a trend to convey to the audience through the liturgy the New Testament role of prophets, which inevitably affected church decoration. This new trend, observed in the decoration of the New Tokal1, is a reflection of changes in Byzantine liturgy. That is probably why prophets were depicted together with New Testament scenes in church decoration. No doubt the educated author of the Tokalı program was also aware of the new developments in Constantinople, that is, of the depictions of prophets with inscribed scrolls, which were already popular in the decoration of Constantinopolitan churches as well as illustrations of prophet books. The author or authors of the New Tokalı incorporated prophets into a program stressing the paschal cycle, and Christ's death and resurrection, suitable for a funeral chapel. In the case of the scene of Pentecost, the prophet Joel bore a text from the Acts quoting his own book, and his figure was juxtaposed to the evangelist Luke (author of Acts). The goal was to convey to the public the presence of prophets in the New Testament event. Visually, they appear, as forming part of the New Testament scenes. At the same time, they came from the contemporary liturgy, which makes them active participants in the church ritual.

The evidence presented above suggests that the patrons of the New Tokalı were not only familiar with the art of Constantinople, but were also aware of the Constantinopolitan usage of liturgical texts in the cathedral rite of Hagia Sophia. The appearance of prophets with inscribed scrolls in the New Tokalı can be viewed as a single example of implementation in local church decoration of the Constantinopolitan liturgy with which the commissioner or designer of the New Tokalı program was no doubt familiar. The New Tokalı presents a unique phenomenon of the representation of prophets near New Testament scenes in local Cappadocian church decoration. It suggests that such a phenomenon may have existed in the Byzantine capital and other Byzantine provinces, as well as in the Christian East (Cyprus and Egypt). Such examples also show that patrons were attentive to changes in art and liturgy and implemented new ideas when the opportunity arose. op.cit. (n. 1), 166-68. 


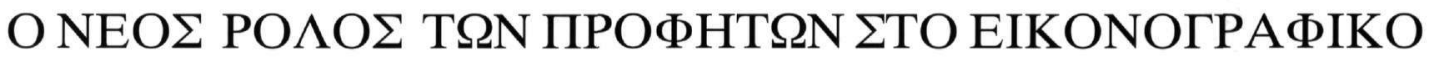

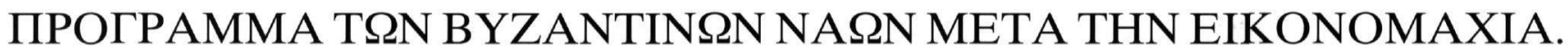 H ПЕРIПT $\Omega$ $\Sigma$ H TH $\Sigma$ NEA $\Sigma$ EKK $\Lambda H \Sigma$ IA $\Sigma$ TOKALI $\Sigma$ THN KAППA $\Delta$ OKIA}

$\mathrm{H}$

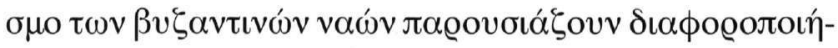

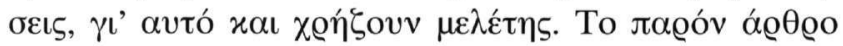

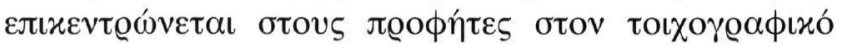

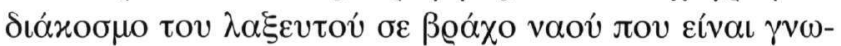

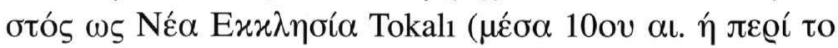

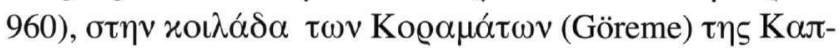

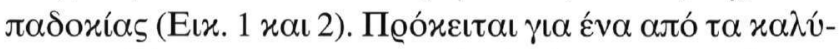

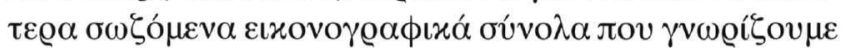

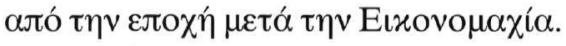

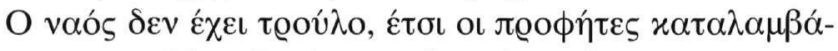

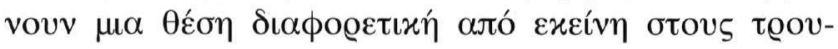

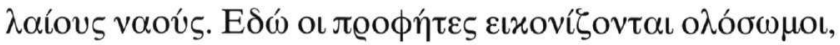

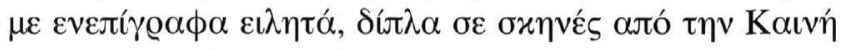

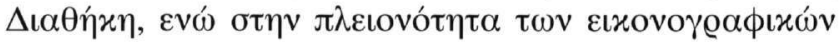

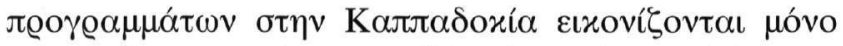

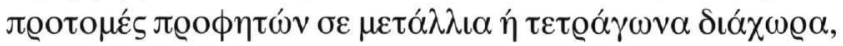

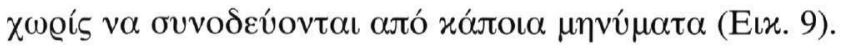

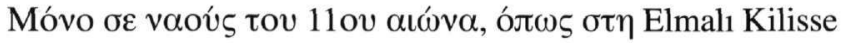

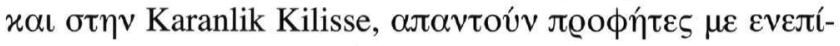

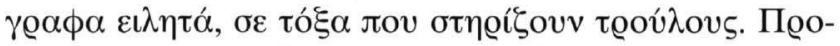

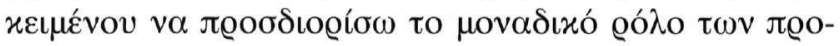

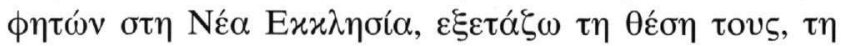

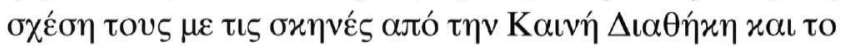

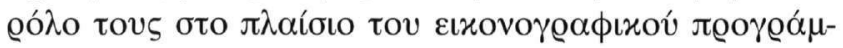

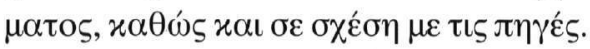

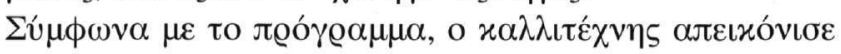

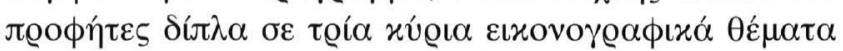

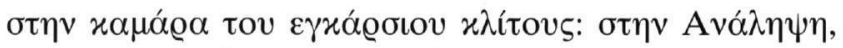

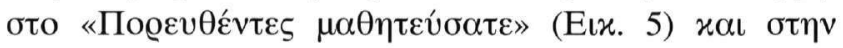

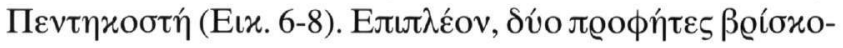

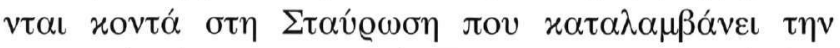

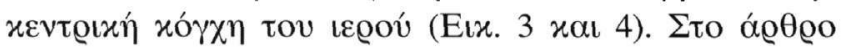

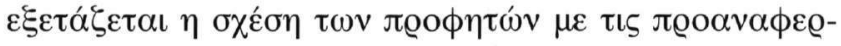

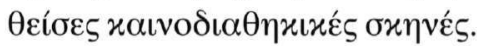

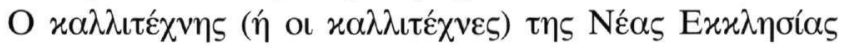

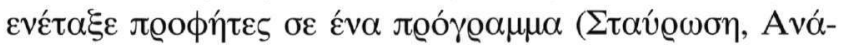

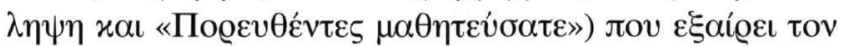

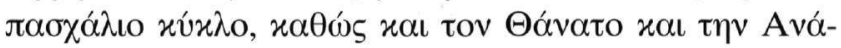

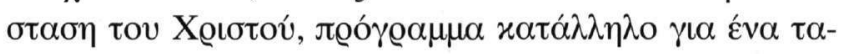

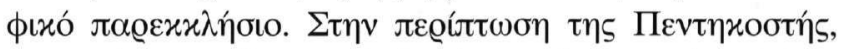

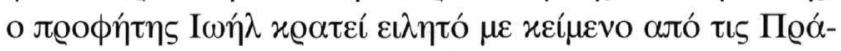

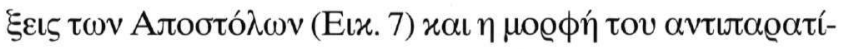

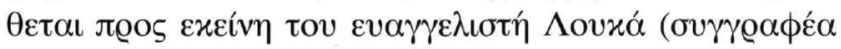

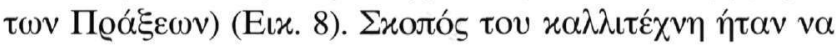

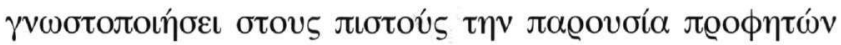

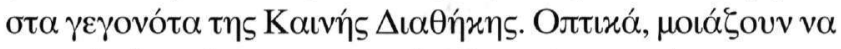

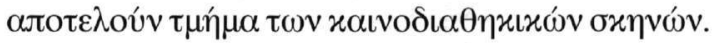

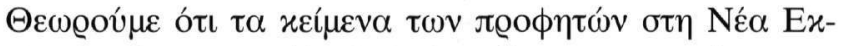

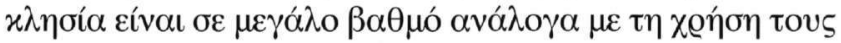

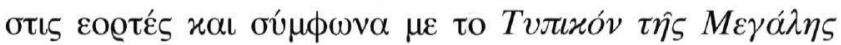

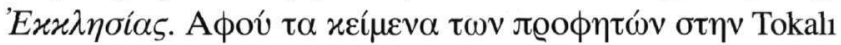

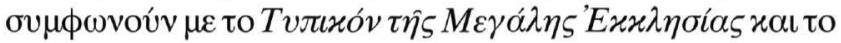

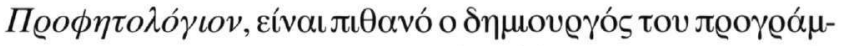
$\mu \alpha \tau$

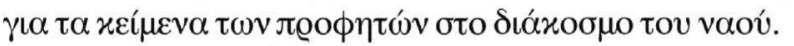

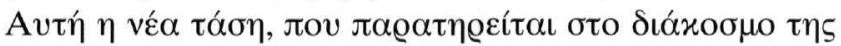

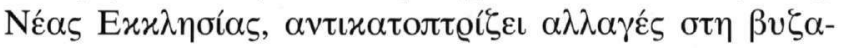

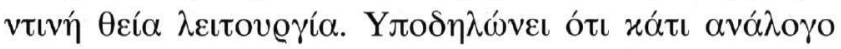

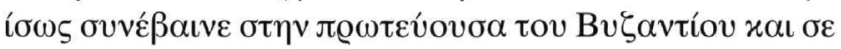

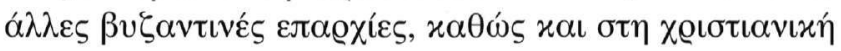

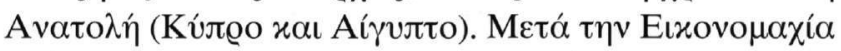

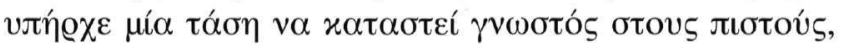

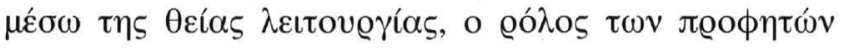

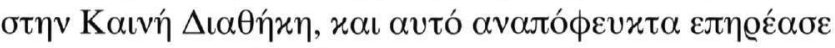

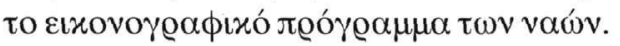

